\title{
THE INFLUENCE OF YOUTH TOURISM ON THE IMAGE OF THE TERRITORY AS A TOOL OF SOFT POWER IN THE CONTEXT OF CONTEMPORARY INTERNATIONAL RELATIONS
}

\author{
Babek Rashid ogli Asadov \\ Saint Petersburg State University of Economics, Saint Petersburg, Russian Federation
}

\author{
Aleksandr S. Baranov \\ Herzen State Pedagogical University of Russia, Saint Petersburg, Russian Federation
}

\begin{abstract}
The article is devoted to analysis of youth tourism as a specific socio-cultural formation of the image of the territory, countries in the international youth environment. This is especially true in the context of tourism active interaction of youth, which sets the stage for the development of multidirectional trends in the international stage. The authors refer to the analysis of some aspects of this phenomenon in the context of contemporary international relations, in which there is a clear movement towards the universalization of youth tourism. Today the trend of transition of youth relations and tourism contacts to the area of international politics and public diplomacy is being shaped more and more clearly. For the first time attempt to understand the role of youth tourism as a mechanism of soft power of Russia, allowing it to be used as an in-demand feedback channel with foreign youth, and the role of social and cultural influence on the international space are presented. The authors discuss the problems of formation of image of the country from the point of view of effective use of the potential of having a "protracted" form of development of the Institute for international youth tourism, as a part of foreign cultural policy of Russia. The authors identified the main problematic aspects and factors that characterize a promising role and place of youth tourism as a desired tool of soft power and channels of influence of Russia in the international space.

Key words: image of the territory, soft power, international youth tourism, international humanities cooperation, foreign cultural policy, humanities influence, image space.

Citation. Asadov B.R., Baranov A.S. The influence of youth tourism on the image of the territory as a tool of soft power in the context of contemporary international relations. Vestnik Volgogradskogo gosudarstvennogo universiteta. Serija 4, Istorija. Regionovedenie. Mezhdunarodnye otnoshenija [Science Journal of Volgograd State University. History. Area Studies. International Relations], 2017, vol. 22, no. 2, pp. 137-148. (in Russian).
\end{abstract}

УДК $327(091)$

ББК 66.4

Дата поступления статьи: 05.11.2016

Дата принятия статьи: 27.02.2017

\section{О ВЛИЯНИИ МОЛОДЕЖНОГО ТУРИЗМА \\ НА ФОРМИРОВАНИЕ ИМИДЖА ТЕРРИТОРИИ КАК ИНСТРУМЕНТА «МЯГКОЙ СИЛЫ» В КОНТЕКСТЕ СОВРЕМЕННЫХ МЕЖДУНАРОДНЫХ ОТНОШЕНИЙ}

\author{
Бабек Рашид оглы Асадов \\ Санкт-Петербургский государственный экономический университет, \\ г. Санкт-Петербург, Российская Федерация
}




\title{
ПОЛИТИЧЕСКИЕ НАУКИ И РЕГИОНОВЕДЕНИЕ
}

\author{
Александр Сергеевич Баранов \\ Российский государственный педагогический университет им. А.И. Герцена, \\ г. Санкт-Петербург, Российская Федерация
}

\begin{abstract}
Аннотация. Статья посвящена анализу молодежного туризма как одного из специфических социальнокультурных инструментов формирования имиджа территории стран в международной молодежной среде. Авторы обращаются к анализу некоторых особенностей данного феномена в контексте современных международных отношений, в рамках которых происходит явное движение к универсализации молодежного туризма. И сегодня все отчетливее вырисовывается тенденция перехода молодежных связей и туристских контактов в область международной политики и публичной дипломатии. Впервые представлена попытка осмысления роли молодежного туризма в качестве механизма «мягкой силы» России, позволяющей использовать его как востребованный канал обратной связи с зарубежной молодежью, так и в роли социокультурного влияния на международное пространство. Рассматривается проблема формирования имиджа страны с точки зрения более эффективного использования потенциала института международного молодежного туризма, как составная часть внешней культурной политики России. Выявлены основные проблемные аспекты и факторы, характеризующие перспективную роль и место молодежного туризма в качестве востребованного инструмента «мягкой силы» и канала влияния России на международное пространство.

Ключевые слова: имидж территории, «мягкая сила», международный молодежный туризм, международное гуманитарное сотрудничество, внешняя культурная политика, гуманитарное влияние, процесс освоения пространства, имажинальное пространство.

Цитирование. Асадов, Б. Р. О влиянии молодежного туризма на формирование имиджа территории как инструмента мягкой силы в контексте современных международных отношений / Б. Р. Асадов, А. С. Баранов // Вестник Волгоградского государственного университета. Серия 4, История. Регионоведение. Международные отношения. - 2017. - Т. 22, № 2. - С. 137-148.
\end{abstract}

Развитие международных отношений в последние десятилетия выявило наличие некоторых объективных закономерностей формирования имиджа территории. Изучение данного процесса свидетельствует о все возрастающей роли макросоциальных факторов, которые вытекают из потребности общества в инновационных типах и оптимальных формах освоения пространства. Это происходит в результате взаимодействия между ключевыми субъектами международного права с целью обеспечения конкурентного преимущества отдельных его участников с более широкими функциями, но при этом доступными средствами. Современное общество все чаще и интенсивнее ищет пути оказания подобного воздействия опосредованно - в форме различных инструментов международного взаимодействия в определенных сферах, где получение желаемых результатов за счет фактора инновационного применения стратегических ресурсов, так называемой «мягкой силы» («soft power»), играет гораздо более важную роль, чем прежде.

На фоне динамично меняющейся социально-экономической и политической реальности возрастает способность некоторых го- сударств и негосударственных акторов вызывать однополярное, но при этом многовекторное и целенаправленное возмущение сложившейся структуры мирового культурного, социально-экономического и политического пространства. Очевидно, что данный аспект поведения международных акторов связан с их специфическими интересами и постоянно растущими потребностями. В свете выявленных тенденций возникает острая необходимость обеспечения безопасности и сохранения собственной идентичности, а следовательно, вызревает неизбежность поиска новых возможностей и разработки более эффективных механизмов гуманитарного взаимодействия, особенно на международной арене. Безусловно, отдельные государственные акторы, активно используя те или иные инструменты и стратегические ресурсы, целенаправленно занимаются продвижением своего положительного имиджа как выражением общественных ожиданий, но вполне очевидно, что подобных несистемных усилий недостаточно.

Формирование положительного имиджа территории - сложный, многосторонний и длительный процесс, который является од- 
ной из приоритетных внешнеполитических задач многих государств. При этом реализация подобной задачи зачастую сталкивается с серьезными системными и структурными проблемами внутреннего и внешнего характера, так как существуют различные (а часто и противоречивые) «взгляды» на саму природу данного процесса, что может привести к столкновениям интересов элит, особенно представляющих самые радикальные точки зрения. Поиск наиболее эффективных инструментов формирования имиджа территории на международной арене осуществляется с использованием (не всегда рациональным) всех доступных ресурсов и резервов, в том числе принадлежащих будущим поколениям, что приводит к нарушению существующего баланса. Баланс политических сил, наступивший после окончания Второй мировой войны, был достигнут во многом в результате применения «жесткой» военной силы и продемонстрировал наличие четко определенных границ ее применения с появлением оружия массового поражения. Поэтому стремление достигнуть желаемого результата без получения неприемлемого ущерба, воздействовать на восприятие мирового сообщества наравне с традиционными, исторически сложившимися методами и средствами и определяет появление новых, более эффективных инструментов «мягкой силы».

В процессе расширения каналов влияния государственных акторов на внешний мир, особенно специфического характера, все отчетливее проявляется потребность в научном осмыслении выстраивания стратегии их развития и использования. Именно эффективная стратегия и своевременные действия в этой области дают им возможность оказывать «адресное», скрытое (манипулятивное) влияние на различные процессы международной жизни.

Безусловно, вокруг дефиниции «мягкой силы» в последнее время возникло дискуссионное поле, в котором особое значение уделяется изучению различных сторон социальных, культурных, экономических и политических явлений международной жизни [15]. Увеличение роли «мягкой силы» отражается в официальных документах, где для решения внеш- неполитических задач в дополнение к традиционным дипломатическим методам рекомендуется использование инструментов «мягкой силы» прежде всего с учетом возможностей гражданского общества, информационно-коммуникационных, гуманитарных и других методов [7].

В этом плане немаловажный интерес в теоретическом и практическом плане, на наш взгляд, представляет философское и научное переосмысление роли современного туризма как процесса освоения территории, расширения границ интеграции, развития международного сотрудничества и, соответственно, социально-культурного фактора поддержания международного престижа страны.

Космополитизация туризма как феномена и его использование в качестве инструмента «мягкой силы» для достижения цели по формированию положительного имиджа территории на международной арене превращаются, возможно, в одну из новых парадигм в изучении закономерностей развития международного сотрудничества современного периода. В рамках формирования глобального, в том числе и туристского, пространства у разных акторов международных отношений значительно возрастают гуманитарные и политические потребности. Данный процесс неизбежно приводит к необходимости глубокого научного осмысления международного туризма в качестве специфического и приоритетного канала воздействия на внешний мир - инструмента «мягкой силы». Так, например, Д. Мак-Клори (Jonathan McClory) рассматривает «перспективы усиления британской “мягкой силы” через фокус экономической и туристической деятельности» [11, p. 42].

Практика эффективного использования туристского потенциала во многом благоприятно сказывается на расширении границ международного гуманитарного сотрудничества. Например, в японской культуре, образовании и творческом контенте появился ряд институтов в сфере формирования образа страны на международной арене [5]. Указанные привлекательные особенности стран часто побуждают иностранцев посещать их и соответственно развивать о них должное позитивное представление. 


\section{ПОЛИТИЧЕСКИЕ НАУКИ И РЕГИОНОВЕДЕНИЕ}

Одним из направлений поступательного развития современного туризма, как немаловажного фактора в процессах глобализации и распространения универсальных ценностей демократии и гражданского общества, является его усиливающаяся роль в политической сфере общества. Так, сегодня использование его потенциала для сохранения или развития в политическом отношении лояльной социально-культурной среды не может остаться незамеченным и становится самостоятельным объектом изучения [2].

В этом смысле туризм «как форма "мягкой силы”» [1] в определенной степени оказывает воздействие и на гуманитарные процессы, так как формирует на уровне ощущений у «иностранцев-путешественников» имидж территории. В результате происходит фиксация позитивного, нейтрального или негативного его восприятия в мировом общественном сознании.

На наш взгляд, туризм как инструмент «мягкой силы» - особый вид внешнеэкономической деятельности государства, направленный на формирование желаемого образа территории посредством регулирования туристских потоков, основанный на принципе комплиментарности (комплиментарного действия) [4].

Туризм как самый динамичный вид внешнеэкономической деятельности становится в процессе международного культурного обмена крайне важным инструментом глобального, но в то же время мягкого воздействия. Характер туристского освоения территории определяет необходимость больше акцентировать внимание на его важных организационных и структурных особенностях в арсенале инструментов «мягкой силы». Необходимо подчеркнуть, что глубокое понимание и изучение этого феномена происходят не только в странах Запада, где туризм сыграл важную роль в формировании имиджа отдельных стран, но все чаще он используется странами Азиатского региона для продвижения своих популярных туристских центров [14].

Эти и другие многогранные особенности современного туризма, характеризующие его постепенный переход в область реализации политики «мягкой силы», предлагают ве- сомую альтернативу существующим реальностям - сложным и противоречивым международным отношениям, которые зачастую связаны с применением инструментов «жесткой силы», опирающейся на политику принуждения. И можно полагать, что в ближайшей перспективе развитию этого процесса в немалой степени могут способствовать динамично развивающиеся молодежные связи и особенно потенциал института международного молодежного туризма, все более вовлекающего в свою орбиту миллионы молодых людей со всего мира. При этом необходимо всегда помнить и древнюю восточную мудрость: хочешь победить врага - воспитай его детей, что переводит феномен молодежного туризма в разряд сильнодействующих, но неприметных инструментов «мягкой силы».

Молодежный туризм как вид социальноэкономической деятельности обладает растущей динамикой, которая демонстрирует все большее проникновение в различные сферы общества, что делает его естественным и неотъемлемым каналом международного взаимодействия. Выявленные особенности позволяют характеризовать его в качестве важного инструмента влияния на формирование имиджа территории, что не в последнюю очередь происходит благодаря «эффекту перекрестного опыления» [3].

Отметим, что, несмотря на всю свою важность, понятие и структура международного молодежного туризма как перспективного и востребованного целевого компонента внешней культурной политики, способного оказывать воздействие на другие страны и территории, в отечественной научной литературе разработаны недостаточно. Необходимость признания его перспективы в качестве действенного эффективного и специфического инструмента распространения культурного влияния продиктована тем, что растущие потребности в многогранной деятельности молодежи, как ресурса перемен, находят поддержку не только на уровне центров мировой политики, но и в рамках известных международных организаций. На развитие данного процесса существенным образом воздействуют особенности индивидуальных интересов и установок, ценностных ориентаций субъектов международного права, поэтому организаторы 
молодежного туризма зачастую используют его как инструмент влияния. Немаловажную роль в этом играет и главное свойство туризма как формы освоения пространства: лучше один раз увидеть, чем сто раз услышать. Таким образом, наряду с традиционными инструментами влияния (пропаганда, пиар, политиканство) туризм имеет существенное отличие - формирование личного опыта в процессе исследования территории.

Глубокое осмысление природы международных молодежных связей и особенностей политики «мягкой силы» в качестве инструмента влияния происходит в рамках института международного молодежного туризма, который по-прежнему переживает серьезный дефицит постоянного внимания и должной государственной поддержки, что неизбежно предполагает необходимость рассмотрения наилучших практик как исторического прошлого, так и современного периода.

Как свидетельствует международная практика второй половины XX столетия, в развитие данного процесса были активно включены наиболее популярные и востребованные акторы молодежного туризма, как на уровне национальных, так и международных организаций, структур, предлагавших новые организованные формы международных контактов. В этом плане необходимо обратить пристальное внимание на очевидную тенденцию - начало расширения географии отечественного института международного молодежного туризма, масштабного освоения туристского пространства как одно из наиболее массовых форм сотрудничества.

Несмотря на то что необходимость вовлечения детей и молодежи в туристско-экскурсионную и краеведческую деятельность была признана еще в начальные годы становления советской власти, активное использование их потенциала в качестве средства идеологического влияния во внешней среде произошло только в 50-х гг. ХХ в. (Постановление ЦК ВЛКСМ «Об укреплении связей с молодежными организациями стран народной демократии» 1956 г.). На фоне целенаправленного развития данного международного взаимодействия «баланс между пропагандой и сервисом был нарушен в пользу идеологической составляющей в юбилейном 1968 году» [8].
Ключевым пространством освоения советского туризма в основном являлись территории стран социалистического лагеря. При этом в качестве основного рычага идеологического влияния на страны Запада активно использовалась и международная организованная молодежная среда, где партнерами выступали в основном акторы левого толка. Важным элементом усиления роли молодежи выступали фестивали, которые, по мнению известного американского советолога Ф.Ч. Баргхорна (Frederick Charles Barghoorn), «были в проекте советской общественной дипломатии и хорошо демонстрировали пропагандистскую стратегию СССР» [13].

Использование этих особенностей молодежного туризма, где важное место отводилось Комитету молодежных организаций СССР (1956 г.), Бюро международного молодежного туризма «Спутник» (1958 г.), всегда было актуальным для существующей политической системы. Наиболее заметна его роль как инструмента «мягкой силы» не только в интернационализации молодежных связей и реализации других социально-политических векторов, но и в формировании желаемого имиджа с целью укрепления авторитета советской элиты на международной арене. Интерес в этом плане представляет инструкция, один из пунктов которой ставил прямую задачу перед молодыми советскими туристами необходимость «создания дополнительных благоприятных условий для распространения среди зарубежной молодежи правдивой информации о жизни и достижениях советского народа» [9]. Данный пример наглядно свидетельствует о том, что это направление являлось признанным и значимым инструментом «мягкой силы» в советской политике.

С распадом СССР произошли глубочайшие структурные изменения существующих связей вплоть до фатального разрушения целых институтов. Неудивительно, что былое влияние туризма как важного инструмента международной молодежной солидарности практически аннулировалось. Образовавшийся вакуум привел к стремительному расцвету западных ценностей, подчас повсеместно и слепо, в молодежной «бунтарской» среде.

Вместе с тем на фоне растущей тенденции либерализации, то есть резкого перехода 
от тотального административно-идеологического подхода регулирования туризма к экономическому стимулированию свободного рынка, стало очевидно, что накопленный потенциал института международного молодежного туризма не в полной мере соответствует возросшим потребностям новой российской элиты и новым политическим установкам. Таким образом, его прежний идеологический и гуманитарный потенциал по объективным причинам не мог стать важной предпосылкой для самостоятельного развития в новых социально-исторических условиях. По сути, анализ существующих тенденций в течение последних десятилетий показывает, что сфера отечественного молодежного туризма остается недостаточно развитой. В данном контексте разработанные ранее формы и проекты международных связей как инструмент «мягкой силы» советского наследия не могут отвечать существующим запросам. Но, несмотря на это, сегодня наилучший опыт и практика по-прежнему востребованы и не утратили свою былую международную роль, значимость и актуальность для развития данного направления.

Конечно, в новых условиях состояние института международного молодежного туризма в России, его масштабы на международном уровне существенно выше, чем в предыдущие десятилетия нового исторического периода. Очевидно, что наряду с возникшими благоприятными условиями, после известных негативных событий на рубеже 8090-х гг, сегодня все более востребована и заметна роль данного фактора. Безусловно, этот процесс тесно связан с экономическим, гуманитарным и политическим потенциалом, а также авторитетом государств в мире. Международные молодежные туристские контакты, способствуя укреплению связей, все больше находят понимание и поддержку в рамках таких организаций, как UN, UNESCO, UNWTO, WYSETC и др., а также у отдельных государственных акторов. Акцентируя все большее внимание на целенаправленном развитии данного вида деятельности, они проявляют заинтересованность в использовании туристских связей в качестве признанного канала международного молодежного сотрудничества и обмена. Также следует отметить еще одну особенность современного периода - наличие различных критериев адресного использования потенциала туристских контактов в плане расширения сотрудничества с молодежью других стран, где немалое внимание уделяется проблемам степени лояльности молодых людей по отношению к этим странам.

Вместе с тем в условиях сложившихся непростых отношений между отдельными геополитическими центрами - их взглядами и позициями (в результате распространения «западных» универсальных ценностей демократии и института гражданского общества) усиливаются и внутренние противоречия. Подобный процесс может восприниматься некоторыми региональными элитами страны как скрытая угроза собственным культурным устоям и традициям (идентичности), и прежде всего в наиболее уязвимой «бунтарской» молодежной среде. Так, представление об «американской мечте» или «сытой и богатой Европе» также формируется в основном в детско-юношеском возрасте посредством воздействия кинематографа как вида культурной экспансии - еще одной разновидности «мягкой силы» наряду с лингвистической экспансией [10].

Чрезмерное и агрессивное расширение границ молодежного туризма (как стихийное, так и целенаправленное) на отдельных территориях как многогранный процесс может сопровождаться проявлением неудовольствия и даже антагонизма в плане засилья представителей других культур и народов. Сложные политические события, миграция, экономический кризис, региональные вызовы в разных уголках мира не только вносят значительные изменения в структуру туристских потоков, но и могут изменить содержательную часть молодежного туризма с точки зрения его результативной функции влияния на формирование имиджа территории. Все это негативно сказывается на реализуемых гуманитарных стратегиях отдельных государств, в которых международным молодежным связям придается особое внимание.

Таким образом, сложившаяся международная обстановка также наложила определенный отпечаток и некоторые ограничения на имеющий пока незначительный уровень 
развития молодежных туристских контактов России. В последнее время такая практика негативно влияла на характер и масштабы развивающихся и особенно многогранных российско-германских связей, влияние которых на межгосударственные отношения было весьма очевидным.

Тем не менее сегодня растущее влияние России и даже нахождение ее среди наиболее влиятельных стран по критерию «мягкой силы» [12] не в полной мере обеспечивают условия для формирования необходимых качеств института международного молодежного туризма как активного актора и инструмента воздействия в процессе освоения туристского пространства. Способность быть привлекательным центром притяжения, особенно для тех стран, которые традиционно существуют благодаря мощному притоку молодежи, является стратегической сферой ее гуманитарных интересов и должна опираться на развитые туристские контакты. В этом плане наиболее логичной и близкой орбитой развития международного молодежного туризма в контексте применения «мягкой силы» для России, безусловно, являются территории стран, входящих в интеграционные структуры СНГ, ЕАЭС, ШОС, БРИКС и др. Необходимость обеспечения такой возрастающей роли, в том числе в контексте развития единого гуманитарного пространства, в значительной степени обусловлена существующим дефицитом эффективного применения потенциала международного молодежного туризма как инструмента «мягкой силы». И сегодня его незначительная роль как важного фактора мобилизации встреч и обменов подразумевает целенаправленное развитие не только двух или многосторонних форм взаимодействия на международной арене участников организованной молодежной среды. Качественное вовлечение в данный процесс заинтересованных акторов и широких слоев молодежи, многие из которых, по сути, не должным образом представляют существующую систему международного молодежного сотрудничества и туризма как на региональном, так и на федеральном уровне, требует разработки адресных программ развития на соответствующих уровнях. Несмотря на реализуемые международные проекты и особенно
XIX Всемирный фестиваль молодежи и студентов (2017 г.), международные связи часто ограничены в основном протокольными встречами или проектами и мероприятиями, состав участников которых во многом представлен в незначительном количестве и т. д. Существующее положение вокруг проблем института международного молодежного сотрудничества и туризма все более сказывается на необходимости формирования принципиально иной конфигурации отношений молодежи во внешней среде. Именно конструктивное институциональное развитие данного направления может способствовать максимальному использованию новых возможностей и каналов для широкого участия в международном гуманитарном сотрудничестве со стороны многочисленных участников организованной молодежной среды.

Как показывает анализ прошлой международной практики, широкое привлечение представителей молодого поколения к массовым формам взаимодействия, в том числе за счет постоянных туристских контактов, осуществлялось в значительной мере с учетом их социально-психологических особенностей. Молодые люди всегда были наиболее восприимчивы к новым идеям, тенденциям, трендам, концепциям, которые оказывали немалое влияние на их мировоззрение и стереотипы об окружающем мире, в частности, в формировании туристского имиджа стран, территорий - имажинального пространства.

Безусловно, сегодня гуманитарный компонент социально-культурного и политического влияния молодежного туризма на новые территории весьма ощутим, что в свою очередь создает некоторые предпосылки для формирования новой идентичности среди молодежи, целенаправленно осваивающей туристские пространства. Во время путешествий молодые люди общаются со сверстниками и местными жителями и транслируют новые ценности, знания, которые впоследствии, конечно, способствуют формированию у последних имиджа своей страны и народа и т. д. Посещение другой социокультурной среды помимо формирования общего представления (в результате освоения новых ценностей, чувственных переживаний, позитивных эмоций, сопричастности к иным социально-культур- 


\section{ПОЛИТИЧЕСКИЕ НАУКИ И РЕГИОНОВЕДЕНИЕ}

ным общностям и т. д.) создает образ стран, территорий, а туристы становятся носителями и проводниками приобретенных ценностей чужой культуры в собственном социуме, осуществляя таким образом «перекрестное опыление». Именно имидж отдельных благополучных стран в немалой степени формирует у молодежи туристскую ориентацию - потребность в путешествии, либо, напротив, может сформировать у них устойчивые негативные стереотипы. Например, известная фраза «увидеть Париж и умереть» в прошлые годы обозначала сокровенную мечту миллионов молодых советских людей, к которой многие буквально стремились всю свою жизнь. И это доказывает, что в значительной степени определяющим фактором развития международного молодежного туризма в некоторых странах был сложившийся позитивный имидж городов, территорий и т. д.

Известно, что в СССР также активно использовались ресурсы, которые занимали особое место в формировании туристского имиджа страны. Популярные туристские маршруты, международные молодежные центры, Всемирные молодежные фестивали, города Москва и Ленинград, Золотое кольцо России и другие достопримечательности всегда ассоциировались с имиджем страны в молодежной среде.

Безусловно, туристские представления о различных странах и территориях претерпевают значительную трансформацию, и в новых условиях в молодежной среде появляются новые установки, интересы и стереотипы по отношению к зарубежным путешествиям и их восприятию исходя из существующего имиджа территории страны.

Следует отметить, что культурные, исторические, политические ценности, современные достижения и достопримечательности в качестве приоритетных направлений внешнеполитической деятельности России во многом становятся важными туристскими предпочтениями зарубежной молодежи. Необходимо усиливать работу по организации постоянно действующих многофункциональных международных молодежных центров (Артек, Сириус), рассчитанных на относительно длительное пребывание, совместное проживание, налаживание дружеских контактов, взаимо- действие по различным программам. На наш взгляд, это позволило бы зарубежным сверстникам, которым ранее не приходилось там бывать, близко познакомиться и получить более достоверное представление о многогранной культуре России и традициях народов, ее населяющих. Очевидно также, что одним из важнейших факторов, определяющих имидж страны за рубежом, являются объекты Всемирного наследия ЮНЕСКО. Их неоценимое значение в качестве фактора, способствующего развитию международного молодежного гуманитарного взаимодействия и туризма, широко признано [6].

Конечно, роль и место уникальных объектов туристско-экскурсионного показа, достопримечательностей, институциональных механизмов и других ресурсов России в качестве средств формирования ее международного позитивного имиджа в международной молодежной среде требуют осмысления и отдельного изучения. Отметим, что не менее важным фактором в международном молодежном туризме и сотрудничестве является самореализация молодых людей в результате новых путешествий и взаимодействия со сверстниками из других стран. Ведь не стоит забывать, что туризм - это прежде всего экспорт и импорт впечатлений. Наряду с вышеназванными качествами молодежи и ее туристскими предпочтениями необходимо отметить, что определенная часть из них - это будущая элита своих стран, мировоззрение которой в немалой степени формируется, в том числе, под влиянием внешних политических и культурных тенденций (во время учебы за рубежом, в рамках взаимодействия со сверстниками из других стран, сетевого общения и т. д.).

В современном мире на фоне в целом отсутствующих явных преград в этом направлении, по сравнению с эпохой холодной войны, данная тенденция характерна и для современного российского общества. Его важная характерная особенность заключается в том, что сфера международного молодежного туризма не освободилась от множественных проблем и предпочтений и ее развитие во многом определяется экономической и социально-политической конъюнктурой и влиянием других факторов динамики межгосударственных отношений. В целом к причинам, которые создают 
неблагоприятные условия для развития международного молодежного туризма, следует также отнести отсутствие не только развитой материально-технической базы, но и его нормативно-правовых основ. В связи с этим нужно не только минимизировать возможное воздействие этих факторов на молодежные туристские связи, но и изучать влияние традиционалистских моделей восприятия России и отдельных стран в молодежной среде.

Это наводит на мысль, что с целью качественного развития института молодежного туризма и определения его целевых функций при использовании потенциала во внешней среде как перспективного инструмента «мягкой силы» государство должно не только обладать определенным уровнем устойчивого социально-экономического развития, культурных и научных достижений, но и создать наиболее привлекательные условия вовлечения заинтересованных участников к формированию полноценного национального института молодежного туризма, предоставляющего различные возможности самореализации. Вместе с тем все большую необходимость приобретает разработка специализированных маршрутов и проектов, ориентированных на зарубежную молодежную аудиторию, и, конечно же, нужно предлагать новые концепты с целью качественного использования потенциала молодежи на международной арене. Туристские связи как средства формирования единой системы взаимодействия молодежи и ее акторов, несомненно, должны стать стимулом развития нового молодежного туристского пространства, оказывающего благоприятное влияние на процесс гуманитарной интеграции и проекты сближения в других областях.

Значительным ресурсом является международное молодежное сотрудничество негосударственных акторов, которое во многом осуществляется вне единого профессионального сообщества. На фоне растущей актуальности использования его многоаспектного потенциала, например, в качестве инструмента влияния на формирование позитивного образа страны в международной молодежной среде, выдвигаются инициативы и проекты, направленные на создание федеральной площадки взаимодействия различных структур. Отсутствие должной информации о потенциале мо- лодежного туризма на страницах специализированных уполномоченных учреждений, например, на сайтах зарубежных офисов ФГУП «Национальный маркетинговый центр по туризму» («Visit Russia») ${ }^{1}$ и др., деятельность которых направлена, в том числе, на формирование положительного образа России, свидетельствует о необходимости создания профессиональной площадки взаимодействия. В этом плане заслуживает пристального внимания программа развивающейся организации - «Ассоциации международного молодежного сотрудничества и туризма» (СанктПетербург $)^{2}$. Выстраивая отношения в рамках формирования единой общероссийской платформы с профильными организациями и структурами, она содействует вовлечению молодежи в процессы туризма, осуществляет деятельность, направленную на развитие института международного молодежного сотрудничества, одной из задач которой является создание условий для формирования положительного образа России.

Важное значение имеет и тот факт, что государство, несомненно, должно создать наиболее благоприятные условия для заинтересованности всех участников сферы международного молодежного туризма и поддержать пути и проекты, направленные на качественное использование его потенциала, который в международном гуманитарном сотрудничестве расширяет роль эффективного использования фактора «мягкой силы», в том числе и в идеологическом плане. Особое значение в этом контексте приобретает организация внутреннего молодежного туризма - невозможно ретранслировать свою многонациональную культуру без непосредственного контакта с ней. Действия, направленные на формирование новой организованной молодежной туристской среды и ее эффективное развитие, должны качественным образом вписываться в общую логику расширения границ внешней культурной политики России, которая в состоянии открыть новые просторы для широкого спектра идей и форм международного молодежного взаимодействия, в том числе с помощью туристских контактов. Очевидно, что это становится возможным только при направленном государственном регулировании туристских потоков, использовании туризма как инструмента «мягкой силы». 


\section{ПОЛИТИЧЕСКИЕ НАУКИ И РЕГИОНОВЕДЕНИЕ}

Таким образом, можно констатировать, что большой интерес представляют наблюдаемые в последние десятилетия тенденции процесса «затяжного» выхода из кризиса института постсоветского международного молодежного туризма, а следовательно, проблемы субъектности и использования его потенциала во внешней культурной политике России. Вместе с тем исследователи не должным образом фокусируют свое внимание на проблемах его использования как необходимого фактора имажинальности (расширения границы пространственного восприятия) в контексте продвижения образа России в международном пространстве, который все больше демонстрирует свои возможности в качестве важного глобального центра социокультурного влияния и притяжения.

Развитость международных связей и острой конкуренции, в том числе ее растущие потребности в сфере обеспечения гуманитарного присутствия, не только создает объективную необходимость в осмыслении роли данного фактора во внешней культурной политике, но и требует разработки постсоветской концепции развития института международного молодежного туризма как перспективного инструмента «мягкой силы». При этом эффективность реализации этой концепции в значительной степени зависит от правильного взаимодействия всех участников, деятельность которых прежде всего ориентирована на запросы зарубежной аудитории.

Немаловажное значение в формировании имажинального пространства приобретает и организация структуры внутреннего молодежного туризма, который как важное перспективное направление туристского процесса соединяет в себе различные социальные и культурные механизмы в качестве равнозначных по влиянию факторов на восприятие молодежи об окружающем мире. Возможность использования молодежного туризма в качестве инструмента «мягкой силы», предоставляющего дополнительные каналы влияния на международное пространство, должна носить не просто желаемый характер, но и стать необходимым условием осуществления деятельности всех участников данного института в целях формирования положительного имиджа территории.

\section{ПРИМЕЧАНИЯ}

${ }^{1}$ Национальный офис по туризму «Visit Russia» в Великобритании. URL: www.visitrussia.org.uk.

${ }^{2}$ «Ассоциация международного молодежного сотрудничества и туризма». URL: www.saintpetersburgcb.com/partners/66/.

\section{СПИСОК ЛИТЕРАТУРЫ}

1. Александрова, М. В. Туризм как форма «мягкой силы». Проблемы китайского путешественника в России / М. В. Александрова. - Электрон. текстовые дан. - Режим доступа: http://www. odnako.org/blogs/turizm-kak-forma-myagkoy-siliproblemi-kitayskogo-puteshestvennika-v-rossii/ (дата обращения: 15.09.2016). - Загл. с экрана.

2. Асадов, Б. Р. О влиянии молодежной среды на процесс туристского освоения политической сферы общества / Б. Р. Асадов, А. С. Баранов // Вестник Пермского университета. Серия «Политология». - 2015. - № 2. - С. 165-176.

3. Гладкий, Ю. Н. Гуманитарная география как научное познание / Ю. Н. Гладкий. - М. ; Берлин : Директ-Медиа, 2016. -544 с.

4. Гумилев, Л. Н. Этногенез и биосфера Земли / Л. Н. Гумилев. - М. : Мишель и К, 1993. - 512 с.

5. Задворная, Е. С. Институционализация образа Японии в государственном внешнеполитическом дискурсе / Е. С. Задворная // Вестник Волгоградского государственного университета. Серия 4 , История. Регионоведение. Международные отношения. - 2016. - Т. 21, № 3. - С. 114-121. - DOI: https://doi.org/10.15688/jvolsu4.2016.3.14.

6. Информационно-экскурсионная деятельность на предприятиях туризма / под ред. Е. И. Богданова. - М. : Инфра-М, 2016. - 384 с.

7. Концепция внешней политики Российской Федерации от 30 нояб. 2016 г. - Электрон. текстовые дан. - Режим доступа: http://www.mid.ru/foreign_policy/ news//asset_publisher/cKNonkJE02Bw/content/id/ 2542248 (дата обращения: 02.02.2017). - Загл. с экрана.

8. Орлов, И. Б. Бюро международного молодежного туризма «Спутник»: между «Сциллой идеологии» и «Харибдой прибыли» / И. Б. Орлов // Проблемы российской истории. - М. ; Магнитогорск : ИРИ РАН : МаГУ, 2010. - Вып. Х. - С. 142-154.

9. Орлов, И. Б. Молодежный выездной туризм в СССР(1958-1970годы) / И.Б. Орлов // ВестникМГОУ. 2013. - № 2. - Электрон. текстовые дан. - Режим доступа: http://evestnik-mgou.ru/vipuski/2013_2/stati/pdf/ orlov.pdf(дата обращения: 25.09.2016). -Загл. с экрана.

10. Фролов, Ф. С. Культурно-лингвистическая экспансия: геополитический аспект / Ф. С. Фролов // Армия и общество. - 2014. - № 4 (41). - С. 17-22. 
11. McClory, J. The Soft Power 30: A global ranking of soft power / J. McClory. - Portland PR Limited, 2015. $-56 \mathrm{p}$.

12. PR-agency Portland Communications. The Soft Power 30. - Electronic text data. - Mode of access: http://softpower30.portland-communications.com/ ranking/ (date of access: 22.09.2016). - Title from screen.

13. Russia's «soft power» strategy / ed. by J. Dougherty; Georgetown University. - Washington, D.C., 2013. - 111 p. - Electronic text data. - Mode of access: https://repository.library.georgetown.edu/ bitstream/handle/10822/709790/Dougherty georgetown_0076M_12414.pdf?sequence=1 (date of access: 01.02.2017). - Title from screen.

14. Shih-Wen, Chen. "Time for Taiwan": Tourism, media, and soft power / Chen Shih-Wen // Chinese soft power and culture: between complicity and independence. - University of Otago : Dunedin, 2013.

15. The new public diplomacy: soft power in international relations / ed. by J. Melissen. - Palgrave, 2005. $-221 \mathrm{p}$.

\section{REFERENCES}

1. Aleksandrova M.V. Turizm kak forma «myagkoy sily». Problemy kitayskogo puteshestvennika $v$ Rossii [Tourism as a Form of "Soft Power". Problems of a Chinese Traveller in Russia]. URL: http://www. odnako.org/blogs/turizm-kak-forma-myagkoy-siliproblemi-kitayskogo-puteshestvennika-v-rossii/. (accessed September 15, 2016).

2. Asadov B.R., Baranov A.S. O vliyanii molodezhnoy sredy na protsess turistskogo osvoeniya politicheskoy sfery obshchestva [On the Influence of Youth Environment on the Process of Tourist Assimilation of Political Sphere of the Society]. Vestnik Permskogo universiteta. Seriya «Politologiya», 2015, no. 2, pp. 165-176.

3. Gladkiy Yu.N. Gumanitarnaya geografiya kak nauchnoe poznanie [Humanities' Geography as a Scientific Cognition]. Moscow; Berlin, Direkt-Media Publ., 2016. 544 p.

4. Gumilev L.N. Etnogenez i biosfera Zemli [Ethnogenesis and Earth's Biosphere]. Moscow, Mishel i K Publ., 1993. 512 p.

5. Zadvornaya E.S. Institutsionalizatsiya obraza Yaponii v gosudarstvennom vneshnepoliticheskom diskurse [Institutionalization of Japan's Image in the Stet Foreign-Political Discourse]. Vestnik Volgogradskogo gosudarstvennogo universiteta.
Seriya 4, Istoriya. Regionovedenie. Mezhdunarodnye otnosheniya [Science Journal of Volgograd State University. History. Area Studies. International Relations], 2016, vol. 21, no. 3, pp. 114-121. DOI: https://doi.org/ 10.15688/jvolsu4.2016.3.14.

6. Bogdanov E.I., ed. Informatsionnoekskursionnaya deyatelnost na predpriyatiyakh turizma [Informational and Excursion Activity in Tourism Companies]. Moscow, Infra-M Publ., 2016. $384 \mathrm{p}$.

7. Kontseptsiya vneshney politiki Rossiyskoy Federatsii ot 30 noyabrya $2016 \mathrm{~g}$. [Conception of Russia's Foreign Policy of November 30, 2016]. URL: http://www.mid.ru/foreign_policy/news// asset_publisher/cKNonkJE02Bw/content/id/2542248. (accessed February 2, 2017).

8. Orlov I.B. Byuro mezhdunarodnogo molodezhnogo turizma «Sputnik»: mezhdu «Stsilloy ideologii» $\mathrm{i}$ «Kharibdoy pribyli» [Bureau of International Youth Tourism "Sputnik": between the "Scylla of Ideology" and "Charybdis of Profit"]. Problemy rossiyskoy istorii [The Problems of Russian History]. Moscow; Magnitogorsk, IRI RAN Publ.; MaGU Publ., 2010, iss. 10, pp. 142-154.

9. Orlov I.B. Molodezhnyy vyezdnoy turizm v SSSR (1958-1970 gody) [Youth Tourism in the USSR (1958-1970)]. Vestnik MGOU, 2013, no. 2. URL: http:// evestnik-mgou.ru/vipuski/2013_2/stati/pdf/orlov.pdf. (accessed September 25, 2016).

10. Frolov F.S. Kulturno-lingvisticheskaya ekspansiya: geopoliticheskiy aspect [Cultural and Linguistic Expansion: Geopolitical Aspect]. Armiya $i$ obshchestvo, 2014, no. 4 (41), pp. 17-22.

11. McClory J. The Soft Power 30: A global ranking of soft power. Portland, PR Limited, 2015.53 p.

12. PR-agency Portland Communications. The soft power 30. URL: http://softpower30.portlandcommunications.com/ranking/. (accessed September 22, 2016).

13. Dougherty J., ed. Russia's "soft power" strategy: A Thesis. Washington D.C., Georgetown University, November 1, 2013. 111 p. URL: https:// repository.library.georgetown.edu/bitstream/handle/ 10822/709790/Dougherty_georgetown_0076M_ 12414.pdf?sequence=1. (accessed February 1, 2017).

14. Shih-Wen Chen. "Time for Taiwan": Tourism, Media, and Soft Power. Chinese soft power and culture: between complicity and independence. Dunedin, University of Otago, November 20, 2013.

15. Melissen J., ed. The new public diplomacy: soft power in international relations. Great Britain, Palgrave Macmillan, 2005. 221 p. 


\section{ПОЛИТИЧЕСКИЕ НАУКИ И РЕГИОНОВЕДЕНИЕ}

\section{Information about the Authors}

Babek Rashid ogli Asadov, Candidate of Sciences (Politics), Associate Professor, Department of International Relations, History and Political Science, Saint Petersburg State University of Economics, Sadovaya St., 21, 191023 Saint Petersburg, Russian Federation, asadovspb@mail.ru, http://orcid.org/ 0000-0003-0956-6388.

Aleksandr S. Baranov, Candidate of Sciences (Pedagogy), Associate Professor, Department of Economic Geography, Herzen State Pedagogical University of Russia, Naberezhnaya reki Moyki St., 48, 191186 Saint Petersburg, Russian Federation, alexandersbaranov@yahoo.com, http://orcid.org/0000-00030958-309X.

\section{Информация об авторах}

Бабек Рашид оглы Асадов, кандидат политических наук, доцент кафедры международных отношений, истории и политологии, Санкт-Петербургский государственный экономический университет, ул. Садовая, 21, 191023 г. Санкт-Петербург, Российская Федерация, asadovspb@mail.ru, http://orcid.org/0000-0003-0956-6388.

Александр Сергеевич Баранов, кандидат педагогических наук, доцент кафедры экономической географии, Российский государственный педагогический университет им. А.И. Герцена, ул. Набережная реки Мойки, 48, 191186 г. Санкт-Петербург, Российская Федерация, alexandersbaranov@yahoo.com, http://orcid.org/0000-0003-0958-309X. 